University of Nebraska - Lincoln

DigitalCommons@University of Nebraska - Lincoln

USDA National Wildlife Research Center - Staff Publications
U.S. Department of Agriculture: Animal and Plant Health Inspection Service

2014

\title{
Fine-scale, spatial and temporal assessment methods for feral swine disturbances to sensitive plant communities in south- central Florida
}

\author{
Rodney K. Felix Jr. \\ USDA/National Wildlife Research Center, rodney.felix.1@us.af.mil \\ Steve L. Orzell \\ Avon Park Air Force Range \\ Eric A. Tillman \\ USDA/APHIS/WS National Wildlife Research Center, eric.a.tillmann@aphis.usda.gov \\ Richard M. Engeman \\ USDA-APHIS-Wildlife Services, s_r100@yahoo.com \\ Michael L. Avery \\ USDA/National Wildlife Research Center, michael.I.avery@aphis.usda.gov
}

Follow this and additional works at: https://digitalcommons.unl.edu/icwdm_usdanwrc

Part of the Life Sciences Commons

Felix, Rodney K. Jr.; Orzell, Steve L.; Tillman, Eric A.; Engeman, Richard M.; and Avery, Michael L., "Finescale, spatial and temporal assessment methods for feral swine disturbances to sensitive plant communities in south-central Florida" (2014). USDA National Wildlife Research Center - Staff Publications. 1491.

https://digitalcommons.unl.edu/icwdm_usdanwrc/1491

This Article is brought to you for free and open access by the U.S. Department of Agriculture: Animal and Plant Health Inspection Service at DigitalCommons@University of Nebraska - Lincoln. It has been accepted for inclusion in USDA National Wildlife Research Center - Staff Publications by an authorized administrator of DigitalCommons@University of Nebraska - Lincoln. 


\title{
Fine-scale, spatial and temporal assessment methods for feral swine disturbances to sensitive plant communities in south-central Florida
}

\author{
Rodney K. Felix Jr • Steve L. Orzell • Eric A. Tillman • \\ Richard M. Engeman • Michael L. Avery
}

Received: 16 January 2014 / Accepted: 21 April 2014 /Published online: 6 May 2014

(C) Springer-Verlag Berlin Heidelberg (outside the USA) 2014

\begin{abstract}
Feral swine are estimated to annually cost hundreds of millions of dollars in economic loss to property and agriculture in the USA, while their ecological consequences remain largely unmeasured. Using submeter-accurate Global Positioning System technology over a multiyear project, we are quantifying in a novel way the spatial and temporal attributes of swine rooting damage within 587 ha of ecologically sensitive wetland plant communities at Avon Park Air Force Range in south-central Florida. We delineated damage polygons from 0.0023 to $4,335 \mathrm{~m}^{2}$ and were able to document recurrent damage through time at most sites during each assessment. For each polygon, we also estimated the age of damage and assigned to it a severity index, qualities of the rooting in which we detected changes in proportions over time. Spatially explicit damage assessments at fine scales conducted over several years can assist land managers in determining effects of rooting on rare plant populations, and will allow investigators to hypothesize what factors are driving patterns of this disturbance across ecologically sensitive plant communities.
\end{abstract}

Responsible editor: Philippe Garrigues

R. K. Felix Jr • E. A. Tillman • M. L. Avery

USDA/National Wildlife Research Center, Florida Field Station,

2820 East University Avenue, Gainesville, FL 32641, USA

S. L. Orzell

Avon Park Air Force Range, 29 South Boulevard, Avon Park,

FL 33825, USA

R. M. Engeman

USDA/National Wildlife Research Center, 4101 LaPorte Avenue,

Fort Collins, CO 80521, USA

Present Address:

R. K. Felix Jr $(\bowtie)$

Eglin Air Force Base Natural Resources-Wildlife, 107 SR 85 North,

Niceville, FL 32578, USA

e-mail: rodney.felix.1@us.af.mil
Keywords Disturbance $\cdot$ Sus scrofa $\cdot$ Florida endemic plants · Seepage slopes $\cdot$ Flatwoods $\cdot$ Wet prairies

\section{Introduction}

Feral swine (Sus scrofa) in Florida are invasive exotics descended mostly from stock introduced by western Europeans in the sixteenth century (Towne and Wentworth 1950 ) and are roughly estimated to cause $\$ 800$ million in damages annually in the USA (Pimentel et al. 2005). Although feral swine are omnivores, their keen sense of smell combined with their capability to overturn soil allows them to exploit subterranean environments for food sources. Feral swine are known to consume and destroy vegetation, especially grasses, sedges, forbs, and some shrubs and trees (Taylor and Hellgren 1997; Cole et al. 2012), and reduce sites they forage to bare, overturned, and excavated soil (Groot Bruinderink and Hazebroek 1996; Chavarria et al. 2007). Furthermore, this rooting alters the provenance of the area (Groot Bruinderink and Hazebroek 1996; Cole et al. 2012), and may increase the ecological invasibility of the site by exotic species (Kotanen 1995; Simberloff and Von Holle 1999; Cushman et al. 2004; Cole et al. 2012), a process which especially should not be ignored in sites with relative high plant endemism. The uprooting, and overturning of vegetation, and displacement and exposure of bare soil in otherwise intact native groundcover vegetation herein is referred to as swine "rooting" and is the focus of our study. Here, we present an approach for obtaining highly accurate swine damage measurements with the versatility to address the spatial aspects of rooting through time. We illustrate the method with examples taken through time in multiple wetland habitats at Avon Park Air Force Range, Florida. 


\section{Materials and methods}

Study area

Avon Park Air Force Range (APAFR) is a 42,430 ha military installation in south-central Florida $\left(27^{\circ} 35^{\prime} \mathrm{N}, 81^{\circ} 16^{\prime} \mathrm{W}\right)$ that was established during World War II for air to ground training and related military missions (Fig. 1). APAFR has numerous species federally (US) listed as threatened or endangered, including many state and globally ( $<20$ sites globally) imperiled plants. APAFR is recognized as a significant conservation management area (Orzell 1997, unpublished report; Stein et al. 2008), and its conservation value is increased because it contributes significant area to an important conservation corridor in Florida along with the adjacent Lake Wales Ridge State Forest, Kissimmee Prairie Preserve State Park, and Three Lakes Wildlife Management Area. The species richness at APAFR contains over $40 \%$ of the native flora known in central Florida, including many narrow- and region-endemic plants. The landscape varies from low-lying long-hydroperiod marshes along the Kissimmee River (elevation of $9.1 \mathrm{~m}$ ), to pine savanna-grasslands with embedded short-hydroperiod marshes on higher terrain, to herbaceous seepage slopes and forested seepage bays on the sideslopes of the Bombing Range Ridge [bisecting APAFR longitudinally (Fig. 1)], to high elevation $(41.2 \mathrm{~m})$ xeric uplands on the ridgetop. At APAFR, some of the highest fine-scale species richness values recorded in North America (27 in $0.1 \mathrm{~m}^{2}, 49$ in $1 \mathrm{~m}^{2}$, and 171
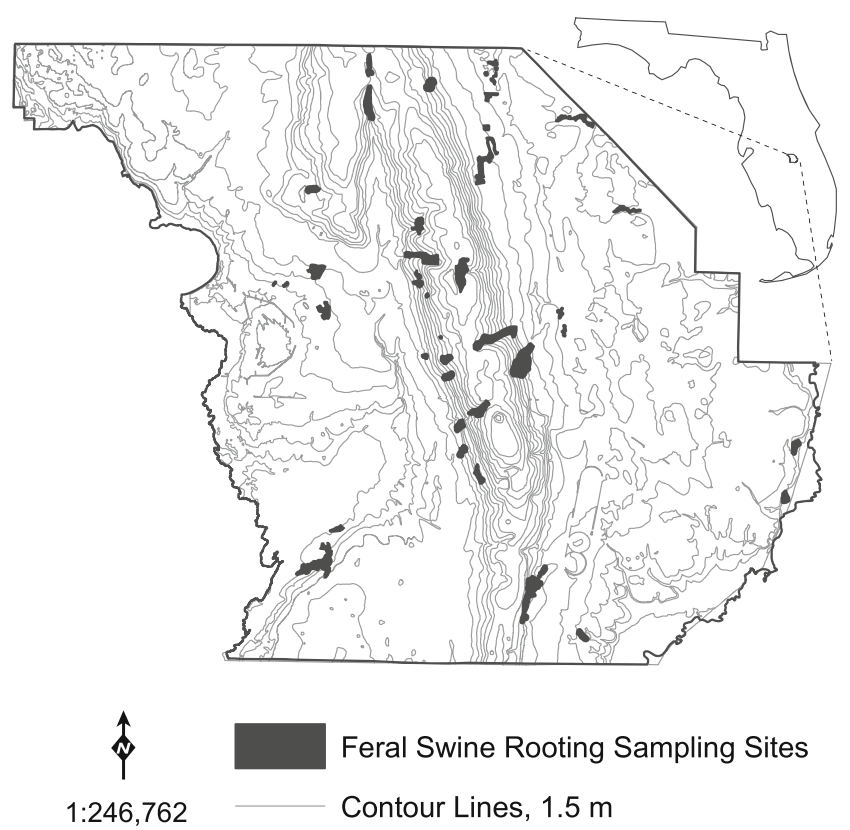

Fig. 1 Forty-nine feral swine rooting survey sites (587 ha total) at Avon Park Air Force Range, located in south central Florida. Most closely placed contour lines define Bombing Range Ridge, a prominent topographical feature running longitudinally through the center of the installation that contributes greatly to the plant biodiversity documented within the range in $1,000 \mathrm{~m}^{2}$ ) have been documented in the groundcover vegetation of the pine savanna-grasslands (Orzell and Bridges 2006a). Additionally, many of the plant community types are globally imperiled simply because they are dominated by endemic plant associations found only in peninsular Florida (Orzell 1997 unpublished report). This rich biodiversity underscores the need to accurately measure the extent and amount of feral swine rooting damage impacting the native flora and vegetation, especially as biodiversity hotspots are also the areas in which most as-yet undescribed species are likely to occur (Joppa et al. 2011).

APAFR has a humid subtropical climate and, based on rainfall data, is conventionally divided into a winter dry and summer wet season (Chen and Gerber 1990; Slocum et al. 2010). The wet season lasts on average 133 days from May 21 to October 1, while the dry season, despite being almost twice as long from October 2 to May 20, has only half the rainfall, thereby drying soil moisture and lowering water levels especially in seasonal low-elevation wetlands. The El Niño Southern Oscillation (ENSO) acts to accentuate or diminish the effects of seasonal precipitation in the region. In particular, in the La Niña phase of ENSO, reduced precipitation creates severe drought during the dry season (Brenner 1991; Beckage et al. 2003), whereas in the El Niño phase, dry season precipitation increases (Donders et al. 2005, 2011). The wet/dry season and ENSO cycle together have a strong influence on hydrology that markedly affects seasonal hydroperiod in wetlands, pine savannas, and grasslands. This, coupled with the pronounced elevational gradient from wet to xeric plant communities, makes some plant communities at APAFR more seasonally exploitable by feral swine rooting damage.

\section{Characterization of sample sites}

The sites we use as examples of our damage assessment approach are being used in a large ongoing multiyear swine damage assessment relative to a swine control program. Initially, 36 sites were randomly selected, but two sites were eliminated due to access restrictions. In the fourth sampling, 15 sites were added to total 49 sites. All sites included for study had to meet one or more criteria: (1) the site had a history of rooting activity, (2) the site had rare plant species, and (3) the site had exemplary sensitive plant communities. The sample sites can be broadly categorized as herbaceous seepage slopes (i.e., seepage slopes $n=26$, total ha $=451$ ), wet pine savanna (also commonly known as wet flatwoods $n=14$, total ha $=62$; and/or wet flatwoods/prairies mosaic $n=4$, total $\mathrm{ha}=52$ ), and wet grasslands (also commonly known as wet prairie $n=5$, total ha=22). Figure 1 illustrates all sample sites on APAFR $(n=49$, site area: $\bar{x}=11.98$ ha, $\min =0.63$ ha, $\max =$ 60.14 ha).

Wet pineland savannas (i.e., wet flatwoods) occur on poorly drained sandy spodosols that often become saturated during 
the wet season but may become desiccated during the dry season. Wet pineland savanna has a scattered or moderately dense canopy of either longleaf pine (Pinus palustris), South Florida slash pine (Pinus elliottii var. densa), or both, with an exceptionally diverse groundcover typically dominated by wiregrass (Aristida beyrichiana) with toothache grass (Ctenium aromaticum), or mono-dominated by cutthroat grass (Coleataenia abscissa) and shrubs such as gallberry holly (Ilex glabra) or wax myrtle (Morella cerifera). In contrast, wet prairies are essentially treeless subtropical wet grasslands that occupy low-lying areas within the pineland landscape, with a 2-4-month hydroperiod, on spodosols or wet sandy entisols often with a shallow muck or mucky sand soil surface (Orzell and Bridges 2006b). The ground cover is species-rich consisting of perennial C4 grasses (40\% or greater mean cover), sedges, and forbs, with little or no shrub cover when frequently burned (Orzell and Bridges 2006b). Although wiregrass (the dominant) is cespitose, many of the grasses in the wet grasslands are rhizomatous or stoloniferous.

Herbaceous seepage slopes occur on the sideslopes of the Bombing Range Ridge, where there is constant groundwater seepage, on mucky or mucky peat histosols. Some seeps are dominated by cutthroat grass, a peninsula Florida endemic C4 perennial grass. Seepage slopes at APAFR support large populations of the globally rare Florida endemic Hartwrightia floridana; moreover, $23 \%$ of the plants found in APAFR seepage slopes are known to be endemic and near-endemic to Florida (Bridges and Orzell 1999). The mixed herbaceous seepage slope, a type of seep that is often dominated by wiregrass and toothache grass, along with a mixture of sedges and herbaceous species, supports many disjunct plants that are rare or at their southernmost range limit. Peninsular Florida herbaceous seepage slopes are globally imperiled (Bridges and Orzell 1999).

\section{Protocol for quantifying damage}

Sampling commenced during the winter dry season, December 2008-January 2009, with two sampling events being completed annually thru 2012: one during November through January [middle-dry season (MDS)] and the other during April through May [late-dry season (LDS)]. We use data from our first eight sampling events in an ongoing study to illustrate our approach and demonstrate its potential for highly accurate spatial analyses of swine damage through time.

We surveyed each site systematically using walking transects, spaced according to the visibility permitted by ground cover, typically $30 \mathrm{~m}$ between transects. Such transect spacing enabled us to detect virtually all rooting per site, as once damage was detected we documented all observable rooting in every direction in succession, until no more rooting was visible, before resuming our track along the transect. We used navigation and mapping functions within each hand-held GPS unit to maintain parallel transects while traversing the uneven terrain; also displayed on the unit were polygons previously recorded that visit that guided observers to/through unsurveyed areas of the site. We mapped swine rooting damage using the hand-held GPS unit [GeoXT ${ }^{\text {тм }}$ GPS receivers (Trimble 2008), or a MobileMapper ${ }^{\mathrm{TM}}$ CX GPS receiver (Ashtech 2009)] to continuously log our position as we walked the perimeter of the rooted area to create a polygon. These GPS units are claimed by their manufacturers to provide submeter accuracy in horizontal measurements, especially when operating under conditions providing percent dilutions of precision (PDOP) of less than 6.0; we recorded all of the rooting polygons with PDOP statuses indicated real-time to be 4.0 or lower. When we logged the perimeter of a damage polygon we also entered categorical values for rooting severity and age, shown in Table 1 . We also entered the percentage of the polygon that was actually rooted as needed, since some otherwise-rooted areas contained remnants of unaltered vegetation. These patches were typically of an area smaller in scale than the manufacturer's claim of "submeter" accuracy, i.e., they were not measurable, yet when added across all polygons, they would have biased our rooting estimates (see results for number of partially rooted polygons). Some polygons were also geometrically complex in such a way as to be challenging to record in the field. Some of these damage polygons could be described as "donut-shaped" and would require separate, concentric polygons that would then need to be subtracted during post-processing. In such cases, we visually estimated the percentage of the total area that was undisturbed to avoid over-quantifying the amount of feral swine damage. Although we noted them, various signs of swine activity other than rooting were not included as measures of activity or impact to sites (feces, trails/tracks, tree rubs, and sightings of individuals).

The rooting polygon data were subsequently converted to GIS-compatible files, using GPS Pathfinder Office ${ }^{\mathrm{TM}}$ (Trimble 2008) and Mobile Mapper Office ${ }^{\mathrm{TM}}$ (Ashtech 2009), and processed within a GIS, ArcMap (ESRI 2011). We inspected each day's polygon data within ArcMap upon conversion to ensure the polygon geometries were consistent with our recollection of the damage we observed in the field. Where they contained obvious geometric anomalies [inaccurate polygon vertices or missing position logs (indicated by straight lines connecting known logged positions)], or perceived spatial/positional errors (when overlaid aerial imagery in GIS, polygons were inconsistent with where we observed the rooting to occur), rooting polygons were re-logged as soon as a return to the site was allowed, and could be sufficiently validated. Figure 2 illustrates such recorded and processed rooting polygons, where their spatial resolution should be noted. We used the GIS to compute metrics such as rooting polygon area and area rooted (percent rooted $\times$ polygon area). Also within ArcMap, measures of central tendency and 
Table 1 Feral swine rooting polygon age and severity assessment criteria for wetland plant communities at Avon Park Air Force Range, Florida

\begin{tabular}{|c|c|c|c|c|}
\hline \multicolumn{5}{|l|}{ Age } \\
\hline Assessment criteria & 1 to 7 days & 8 to 30 days & 31 to 90 days & 91 to 180 days \\
\hline Bare and overturned soil & No plants & Plants newly sprouted & $\begin{array}{l}\text { New plants distinguished } \\
\text { to genus }\end{array}$ & $\begin{array}{l}\text { New plants distinguished } \\
\text { to species }\end{array}$ \\
\hline Overturned vegetation & Green & Yellowing and/or wilted & Mostly dead & Gray/decomposed \\
\hline Exposed roots & Intact/pliable & Intact/dry & Brittle, breaking-off & Brittle/broken-off \\
\hline Disturbed vegetation & Not re-sprouted & Budding leaves and stems & Extended shoots and stems & Moderately recovered \\
\hline Soil texture & Fluffy/moist & Signs of weathering & Weathered, settling and flattening & Settled/dry \\
\hline \multicolumn{5}{|l|}{ Severity } \\
\hline Assessment criteria & Surficial & Moderate & Extensive & wallow \\
\hline Bare soil prevalence & $\leq 33 \%^{\mathrm{a}}$ & Greater than $33 \%$, but less than $66 \%$ & $\geq 66 \%$ & Open depression \\
\hline Plants uprooted/consumed & $\leq 33 \%^{\mathrm{a}}$ & Greater than $33 \%$, but less than $66 \%$ & $\geq 66 \%$ & Devoid of vegetation \\
\hline Rooting depth & At surface ${ }^{\mathrm{b}}$ & Below surface but less than $30 \mathrm{~cm}$ & $\geq 30 \mathrm{~cm}$ & Varying \\
\hline
\end{tabular}

${ }^{\text {a }}$ Percent of rooting polygon

${ }^{\mathrm{b}}$ Rooting polygon maximum depth

variation were generated for the populations of polygons for each site at each damage assessment.

\section{Results}

We measured rooted areas as small as $0.0023 \mathrm{~m}^{2}$ and as large as 4,335.4902 $\mathrm{m}^{2}$. Across all seasons and sites, rooting polygons averaged $25.44 \mathrm{~m}^{2}(n=8,035, \mathrm{SD}=$ 142.24). Of these polygons, we recorded 1,802 smaller in area than $1.02 \mathrm{~m}^{2}$, and 4,927 smaller than $5.02 \mathrm{~m}^{2}$. In fact, we recorded 6,951 polygons with areas smaller than the mean. The frequency distribution of the polygon sizes we measured is far from normal and skewed similarly to the frequency distributions of swine damage previously published (Fig. 3) (Kotanen 1995; Welander 2000). Our mean polygon area is biased high by the few extremely large areas of rooting we detected. Of 1,743 polygons that were partially rooted, 1,045 were estimated to be at least $80 \%$ rooted; 698 polygons ranged between 10 and $75 \%$ partially rooted. We were able to describe the proportion changes over the seasons in rooting damage based upon age and severity (Fig. 4). After three sampling events, we no longer detected rooting whose age we could not determine, and over all seasons we detected less of the "4-6-month" rooting, varying levels of " $2-3$-month" and " $<1$-month" rooting (when combined comprised the majority of rooting each season, beginning the third sampling event), and an amount of " $<1$-week" rooting that varied but was typically the smallest proportion (Fig. 4). From the fourth sampling event onward, the swine damage was dominated by most-severe rooting (Fig. 4).
Many of the survey sites were rooted at each of the sample events, and we were able to observe re-rooting within individual damage polygons at multiple sites, with a noteworthy example shown in Fig. 5. For example, among middle-dry season replicates, the amount of re-rooting between any two MDS seasons (mean \pm sd) averaged $1,719 \pm 940 \mathrm{~m}^{2}$; the amount of re-rooting between any three MDS seasons averaged $373 \pm 193 \mathrm{~m}^{2}$ (Table 2). Among late-dry season surveys, we detected $2,561 \pm 2,780 \mathrm{~m}^{2}$ of two-season re-rooting and $361 \pm$ $263 \mathrm{~m}^{2}$ of three-season re-rooting (Table 2). Twentyseven instances of re-rooting among all MDS seasons totaled $91 \mathrm{~m}^{2}$, and 18 instances among LDS seasons totaled $71 \mathrm{~m}^{2}$.

\section{Discussion}

Popular media and scientific literature continue to report the negative environmental and consequent economic impacts of the foraging behavior of feral swine (Engeman et al. 2003, 2004b, 2007a; Pimentel et al. 2005; Morthland 2011; Tegt et al. 2011). Increasingly too are researchers' efforts describing the negative impacts feral swine have on native ecosystems globally, as well as land managers' attempts to mitigate their damages (e.g., Campbell and Long 2009). However, methods measuring the spatial extent of feral swine damage to ecosystems have not been highly precise, nor have they been conducted over large temporal scales, nor have they been able to spatially document re-rooting events. Early efforts to quantify swine damage did not fully explain how measures of rooting were made (Baron 1982; Groot Bruinderink and Hazebroek 
Fig. 2 Example of rooting polygons recorded during the initial survey season at site 17 at Avon Park Air Force Range, Florida. The image is centered on a forested wetland comprised of Magnolia and Nyssa tree species, surrounded by a zone comprised of Hypericum shrubs and Andropogon grasses, among others. South Florida Slash Pine (P. elliottii var. densa) are prominent in the figure's northwest, and Saw Palmetto (Serenoa repens) in its southeast. Aerial imagery are from an unspecified date in 2008

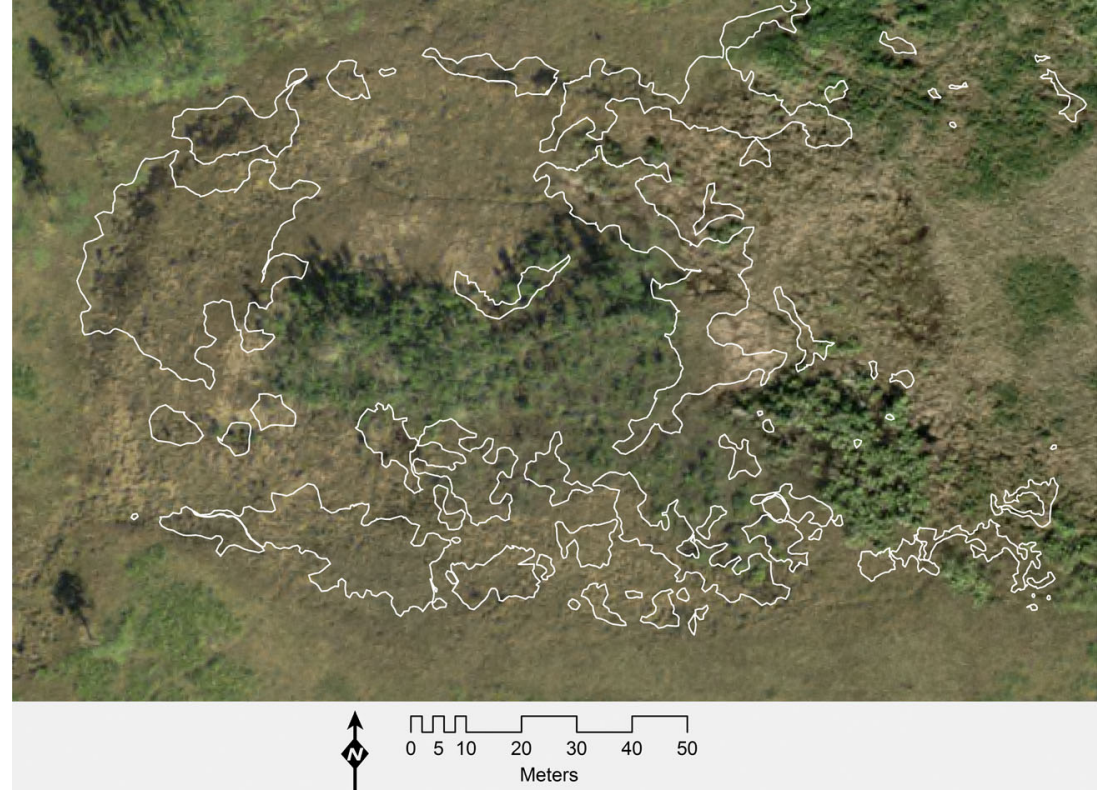

1996). In recent years, measuring and quantifying impacts of feral swine rooting on native ecosystems has increasingly emphasized spatially explicit coverage of damages (Cushman et al. 2004; Engeman et al. 2007b, 2007c; Chavarria et al. 2007), yet these methods have relied on estimating rooted areas using various plot and line-intercept sampling methodologies rather than attempting to account for all incidences of rooting within a survey site. Engeman et al. (2003, 2004a, 2007c) found that sampling the amount of swine rooting over time through line-intercept or plots was a cost- and labor-efficient method for estimating the extent of rooting damage and relating it to changes in swine population size in various Florida natural areas.
Thomas et al. (2013) optimized the application of lineintercept sampling design and estimation procedures for assessing swine damage in light of the practical considerations typical of ecological sampling. In a more spatially explicit manner, Chavarria et al. (2007) used hand-held GPS units to map and estimate damage areas of "simple polygons," which were also sampled from the greater survey area using line-transects. They calculated rooted areas by multiplying the longest length of a polygon by its center-point width, an approach that might overestimate the rooted area, although their data allowed basic spatial interpretations.

Our protocol advances beyond these efforts and capitalizes on technological advances in hand-held/in-the-field GPS units
Fig. 3 Frequency distribution of damage polygons detected across survey seasons (2008-2012) in 49 wetland plant community sites, Avon Park Air Force Range, Florida. Each category bin represents twice the area as its precedent

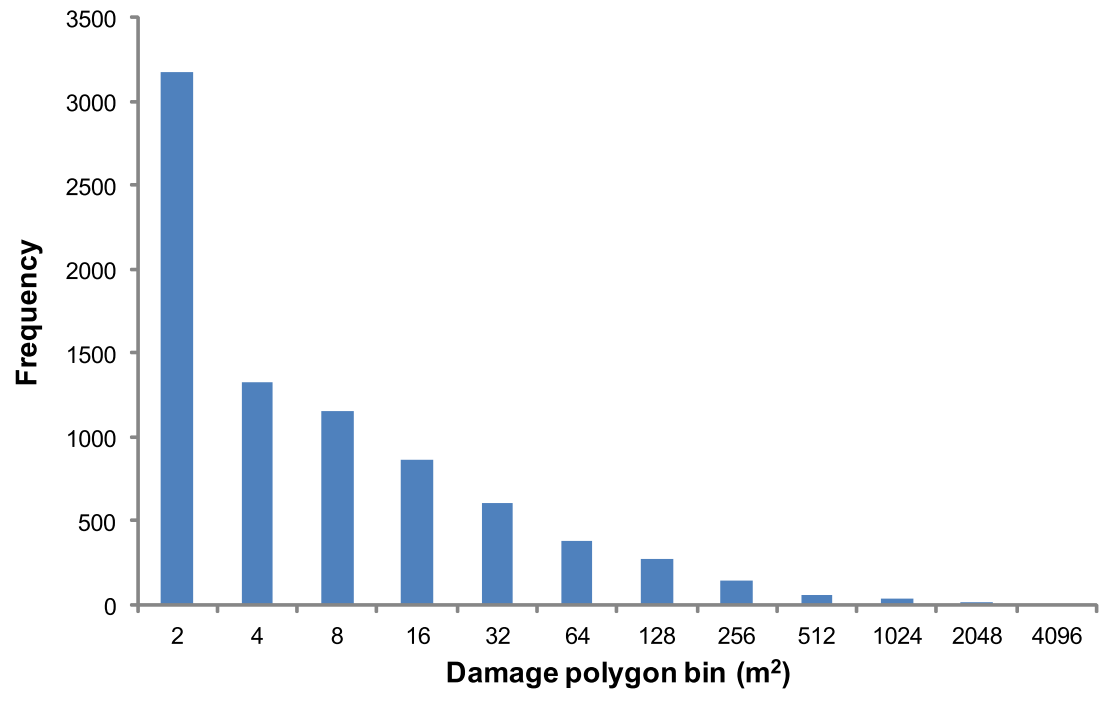


Fig. 4 Proportions of damage each survey season categorized by $\mathbf{a}$ age and $\mathbf{b}$ severity for wetland plant communities at Avon Park Air Force Range, Florida. $M D S=$ middle-dry season, $L D S=$ late-dry season

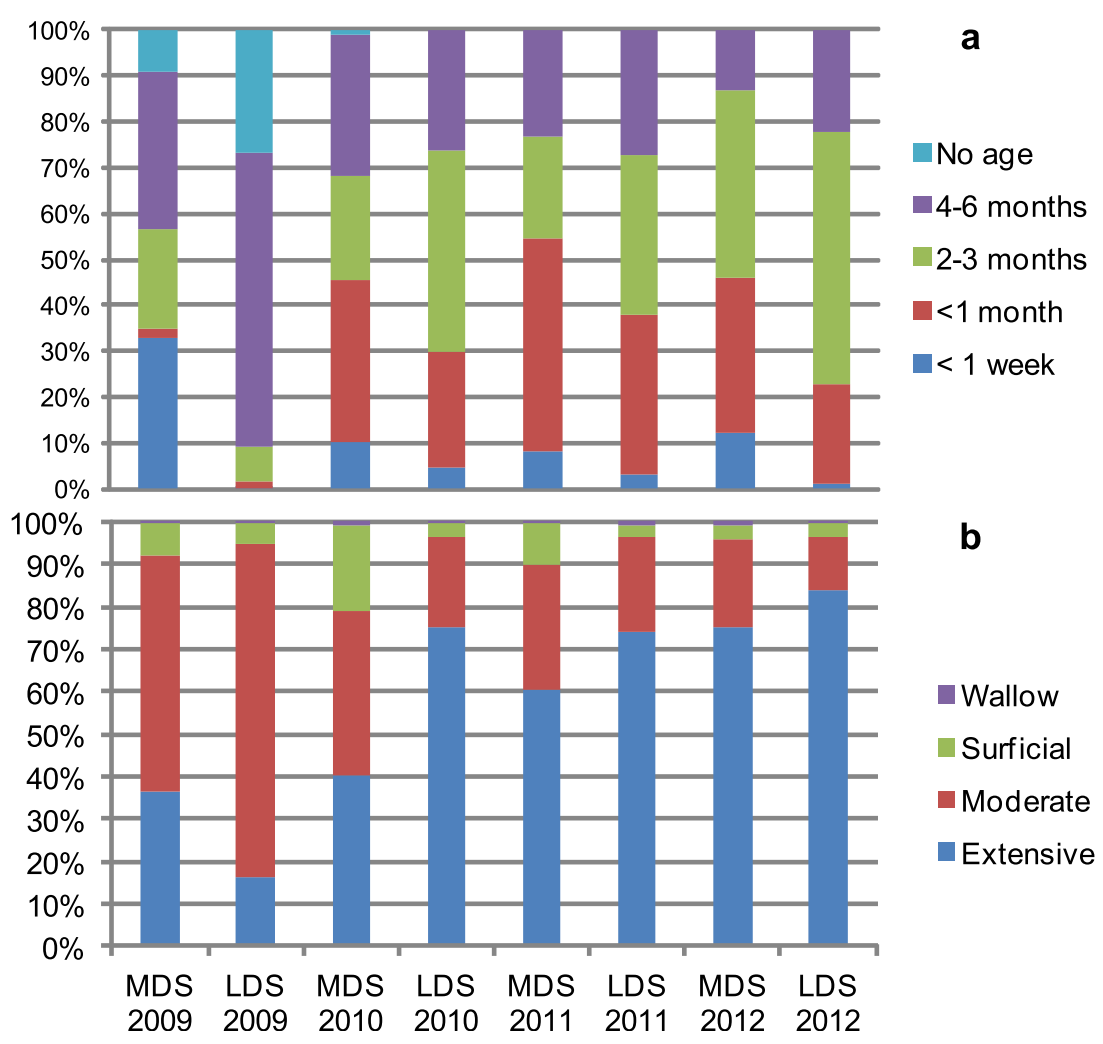

and desktop tools in spatial analytical methods. Unlike previous rooting damage research, our measures differ by the inclusion of the following: (1) highly accurate (submetric) mapping for an entire population of rooted areas within a survey site, (2) mapped data with intact geometries, (3) values recorded for other relevant categorical variables including rooting age and severity indices, and (4) an ability to accurately delineate and measure re-rooting in a previously rooted spot. By assessing swine rooting over multiple sampling events and various seasons, we also were able to incorporate the temporal variable of "timing," which is ecologically significant in an environment that has a strong seasonal climate that is suspected to influence swine behavior (and thereby rooting activity). Tracking rooting explicitly in space and
Fig. 5 Feral swine rooting detected across multiple sampling events at site 17 for wetland plant communities at Avon Park Air Force Range, Florida. $M D S=$ middle-dry season, $L D S=$ late-dry season

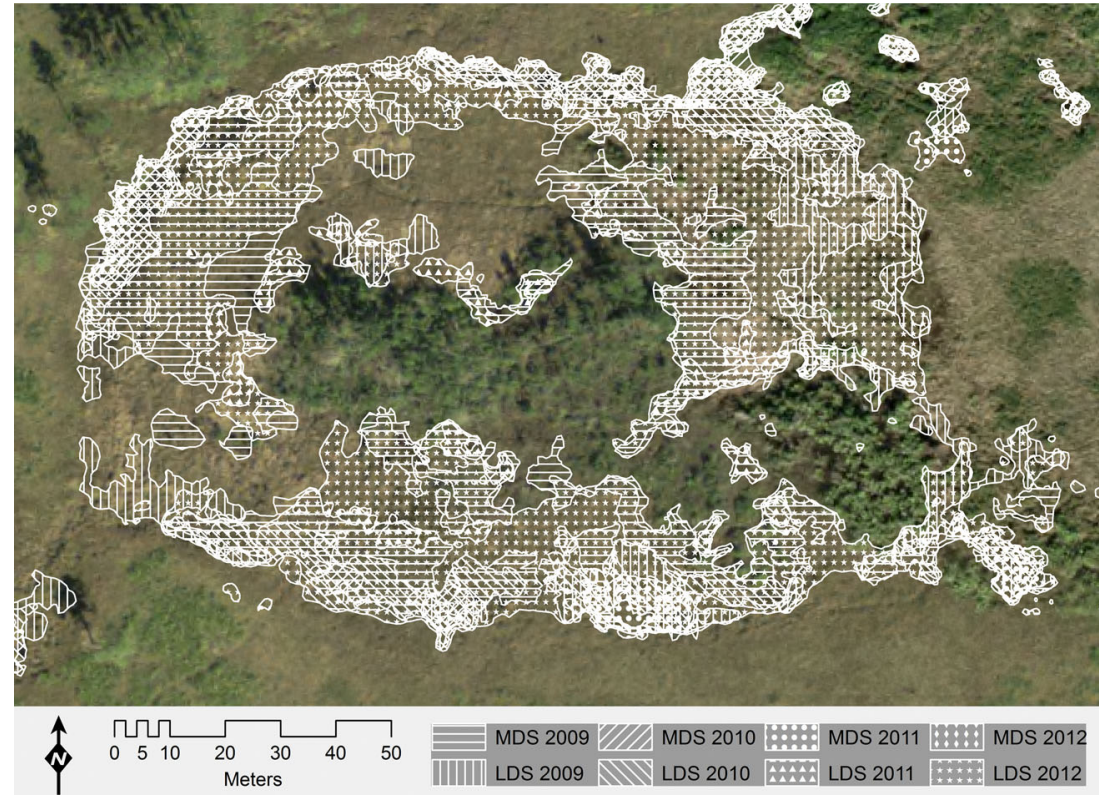


Table 2 Instances of polygon-scale re-rooting among replicate sampling events within the middle-dry seasons (MDS) and late-dry seasons (LDS) for wetland plant communities at Avon Park Air Force Range, Florida

\begin{tabular}{|c|c|c|c|c|c|c|c|c|c|c|c|}
\hline \multirow[b]{3}{*}{ Sampling events intersected ${ }^{\mathrm{a}}$} & \multicolumn{11}{|c|}{ MDS seasons sampling events } \\
\hline & \multicolumn{6}{|c|}{2 Sampling events } & \multicolumn{4}{|c|}{3 Sampling events } & \multirow{2}{*}{$\begin{array}{l}4 \text { Sampling events } \\
1 \cap 3 \cap 5 \cap 7\end{array}$} \\
\hline & $1 \cap 3$ & $1 \cap 5$ & $1 \cap 7$ & $3 \cap 5$ & $3 \cap 7$ & $5 \cap 7$ & $1 \cap 3 \cap 5$ & $3 \cap 5 \cap 7$ & $1 \cap 5 \cap 7$ & $1 \cap 3 \cap 7$ & \\
\hline Number polygons & 218 & 119 & 120 & 129 & 107 & 213 & 58 & 55 & 43 & 58 & 27 \\
\hline \multirow[t]{3}{*}{ Total re-rooted area $\left(\mathrm{m}^{2}\right)$} & 3,556 & 1,763 & 1,131 & 1,099 & 1,174 & 1,593 & 511 & 284 & 145 & 553 & 91 \\
\hline & \multicolumn{11}{|c|}{ LDS sampling events } \\
\hline & \multicolumn{7}{|c|}{2 Sampling events } & \multicolumn{3}{|c|}{3 Sampling events } & 4 Sampling events \\
\hline Sampling events intersected ${ }^{a}$ & $2 \cap 4$ & $2 \cap 6$ & $2 \cap 8$ & $4 \cap 6$ & $4 \cap 8$ & $6 \cap 8$ & $2 \cap 4 \cap 6$ & $4 \cap 6 \cap 8$ & $2 \cap 6 \cap 8$ & $2 \cap 4 \cap 8$ & $2 \cap 4 \cap 6 \cap 8$ \\
\hline Number polygons & 130 & 78 & 132 & 117 & 328 & 291 & 25 & 73 & 63 & 67 & 18 \\
\hline Total re-rooted area $\left(\mathrm{m}^{2}\right)$ & 1,293 & 479 & 2,455 & 778 & 7,991 & 2,373 & 145 & 270 & 285 & 745 & 71 \\
\hline
\end{tabular}

${ }^{a}$ Sampling event $1=$ MDS 2009, sampling event $2=$ LDS 2009, sampling event $3=$ MDS 2010, sampling event 4=LDS 2010, sampling event $5=$ MDS 2011, sampling event $6=$ LDS 2011, sampling event $7=$ MDS 2012, and sampling event $8=$ LDS 2012

time enables identification of damage hotspots and thus can make clear the vulnerability of certain plant communities or sample sites to rooting damage from feral swine. Because we recorded feral swine damage in a spatially explicit manner, overlaying and visualizing exactly where swine repeatedly foraged across seasons was easily accomplished using GIS technology (Fig. 2, Fig. 5). In fact, the ArcGIS software (ESRI 2011) includes a tool that computes geometric intersections of spatially compatible data. Therefore, we were able to determine among sites where rooting hotspots occurred, including the forested wetland within the Seepage Slope community of site 17 (Fig. 5). Spatially explicit, precise datasets also afford analyses that have previously been challenging to evaluate, such as geospatial analysis of damage within a landscape context.

We found that both age and severity classifications required evaluating multiple criteria (Table 1) because post-rooting such "tell-tale" characters of rooting become obscure over time in situ. Our most problematic metric was accurately characterizing the age of rooting activity. For example, there are subtle but noticeable changes in soil texture that occur post-rooting which are often the result of local weather conditions such as precipitation or dew. Furthermore, the timing of postrooting precipitation can influence the amount and developmental stage of detected re-growing vegetation. By conducting our sampling events during the dry season, we attempted to minimize confounding effects that precipitation would have on estimating the age of swine damage. Observer error in estimating the ages of rooting polygons can be reduced with more frequent sample events, but such an increase in sampling while maintaining the same number of observers is prohibitively more costly and labor intensive in large sample areas such as ours (587 ha). Determining the severity of the rooting damage based on four levels was less problematic, especially with the inclusion of depth of rooting (Chavarria et al. 2007).

\section{Conclusions}

Submeter-scale GPS measurements of damage indicate only part of the ecological threat posed by feral swine rooting. Estimating the age and severity of rooting, combined with collecting its spatially explicit measurements, adds conservation value to feral swine damage assessments. The timing of rooting, which may be deduced from age estimates, is particularly important in determining the ecological effects of swine rooting in the seasonal wet/dry climates of the seepage slopes, wet flatwoods, and wet prairies of APAFR - where rooting to sensitive plant communities has varying impacts when soils are dry versus moist (thereby affecting the overall effect on vegetation). Our results, by showing a temporal pattern of seasonal and inter-annual rooting (Fig. 4, Fig. 5), also demonstrate that such analyses are possible. Understanding the damages feral swine rooting causes to unique and vulnerable natural resources is limited without a spatial context and can be enhanced when patterns in the age and severity of rooting are standardized. The capability to spatially and temporally assess the threat feral swine pose to plant communities at fine scales will provide a tool for land managers elsewhere to evaluate the effectiveness of swine management methods (Engeman et al. 2007a). Furthermore, for some land managers, the capacity to accurately quantify rooting, and therefore the capacity to quantify economic impacts of swine damage, justifies measuring their impacts more comprehensively and at finer scales than have been previously reported.

Acknowledgments We appreciate the support of Paul Ebersbach, Chief, Environmental Flight, APAFR, and the USAF for funding this project; and Gary Killian, coordinator of this project for the 
USDA/National Wildlife Research Center. For field assistance, we are grateful to J. S. Humphrey, W. E. Bruce, K. L. Keacher, and E. Fetzer, and for comments on an earlier version of this manuscript we thank M. Slocum. This research was supported through interagency agreement 08-7483-0707(IA) between the National Wildlife Research Center and Avon Park Air Force Range.

\section{References}

Ashtech (formerly Magellan Professional) (2009) MobileMapping, Mobile Mapper Office. Santa Clara, CA http://www.ashtech.com

Baron J (1982) Effects of feral hogs (Sus scrofa) on the vegetation of Horn Island, Mississippi. Am Midl Nat 107:202-205

Beckage B, Platt WJ, Slocum MG, Panko B (2003) Influence of the El Niño-Southern Oscillation on the fire regimes of the Florida Everglades. Ecol 84:3124-3130

Brenner J (1991) Southern Oscillation anomalies and their relationship to Florida wildfire. Fire Manag Notes 52:28-32

Bridges EL, Orzell SL (1999) Cutthroat grass communities. In: South Florida Multi-Species Recovery Plan. U.S. Fish and Wildlife Service, Atlanta, pp 3-347-3-398

Campbell TA, Long DB (2009) Feral swine damage and damage management in forested ecosystems. For Ecol Manag 257:2319-2326

Chavarria PM, Lopez RR, Bowser G, Silvy NJ (2007) A landscape-level survey of feral hog impacts to natural resources of the Big Thicket National Preserve. Hum-Wildl Conflicts 1:199-204

Chen E, Gerber JF (1990) Climate. In: Myers RL, Ewel JJ (eds) Ecosystems of Florida. University of Central Florida Press, Orlando, pp 11-35

Cole RJ, Litton CM, Koontz MJ, Loch RK (2012) Vegetation recovery 16 years after feral pig removal from a wet Hawaiian forest. Biotropica 44:463-471

Cushman JH, Tierney TA, Hinds JM (2004) Variable effects of feral pig disturbances on native and exotic plants in a California grassland. Ecol Appl 14:1746-1756

Donders TH, Wagner F, Dilcher D, Visscher H (2005) Mid to late Holocene El Nino-Southern Oscillation dynamics reflected in the subtropical terrestrial realm. Proc Natl Acad Sci 102:10904-10908

Donders TH, de Boer HJ, Finsinger W, Grimm EC, Dekker SC, Reichart GJ, Wagner-Cremer F (2011) Impact of the Atlantic Warm Pool on precipitation and temperatures in Florida during the North Atlantic cold spells. Clim Dyn 36:109-118

Engeman RM, Smith HT, Shwiff SA, Constantin B, Woolard J, Nelson M, Griffin D (2003) Prevalence and economic value of feral swine damage to native habitat in three Florida state parks. Environ Conserv 30:319-324

Engeman RM, Smith HT, Severson R, Severson M, Woolard J, Shwiff SA, Constantin B, Griffin D (2004a) Damage reduction estimates and benefit-cost ratios for feral swine control from the last remnant of a basin marsh system in Florida. Environ Conserv 31:207-211

Engeman RM, Smith HT, Severson R, Severson M, Shwiff SA, Constantin B, Griffin D (2004b) The amount and economic cost of feral swine damage to the last remnant of a basin marsh system in Florida. J Nat Conserv 12:143-147

Engeman RM, Constantin B, Shwiff SA, Smith HT, Woolard J, Allen J, Dunlap J (2007a) Adaptive and economic management methods for feral hog control in Florida. Hum-Wildl Conflicts 1:178-185

Engeman RM, Woolard J, Smith HT, Bourassa J, Constantin B, Griffin D (2007b) An extraordinary patch of feral hog damage in Florida before and after initiating hog removal. Hum-Wildl Conflicts 1:271-275
Engeman RM, Stevens A, Allen J, Dunlap J, Daniel M, Teague D, Constantin B (2007c) Feral swine management for conservation of an imperiled wetland habitat: Florida's vanishing seepage slopes. Biol Conserv 134:440-446

ESRI (2011) ArcGIS Desktop 10. Redlands, CA http://www.esri.com

Groot Bruinderink GWTA, Hazebroek E (1996) Wild boar (Sus scrofa scrofa L.) rooting and forest regeneration on podzolic soils in the Netherlands. For Ecol Manag 88:71-80

Joppa LN, Roberts DL, Myers N, Pimm SL (2011) Biodiversity hotspots house most undiscovered plant species. Proc Natl Acad Sci 108: 13171-13176

Kotanen PM (1995) Responses of vegetation to a changing regime of disturbance: effects of feral pigs in a Californian coastal prairie. Ecogr 18:190-199

Morthland J (2011) Texans are battling a shockingly destructive invasive species. Smithsonian 41:53-61

Orzell SL, Bridges EL (2006a) Floristic composition and species richness of subtropical seasonally wet Muhlenbergia sericea prairies in portions of Central and South Florida. In: Noss RF (ed) Land of fire and water: the Florida dry prairie ecosystem. Proceedings of the Florida Dry Prairie Conference, October 5-7, 2004, Sebring, pp 136-175

Orzell SL, Bridges EL (2006b) Species composition and environmental characteristics of Florida dry prairies from the Kissimmee River region of south-central Florida. In: Noss RF (ed) Land of fire and water: the Florida dry prairie ecosystem. Proceedings of the Florida Dry Prairie Conference, October 5-7, 2004, Sebring, pp 100-135

Pimentel D, Zuniga R, Morrison D (2005) Update on the environmental and economic costs associated with alien-invasive species in the United States. Ecol Econ 52:273-288

Simberloff D, Von Holle B (1999) Positive interactions of nonindigenous species: invasional meltdown? Biol Invasions 1:21-32

Slocum MG, Platt WJ, Beckage B, Orzell SL, Taylor W (2010) Accurate quantification of seasonal rainfall and associated climate-wildfire relationships. J Appl Meteorol Climatol 49:2559-2573

Stein BA, Scott C, Benton N (2008) Federal lands and endangered species: the role of military and other federal lands in sustaining biodiversity. Bioscience 58:339-347

Taylor RB, Hellgren EC (1997) Diet of feral hogs in the western South Texas Plains. Southwest Nat 421:33-39

Tegt J, Mayer J, Dunlap J, Ditchkoff S (2011) Plowing through North America. Wildl Prof 5:36-39

Thomas J, Engeman RM, Tillman EA, Fischer JW, Orzell SL, Glueck DH, Felix RK Jr, Avery ML (2013) Optimizing line intercept sampling and estimation for feral swine damage levels in ecologically sensitive wetland plant communities. Environ Sci Pollut Res 20:1503-1510

Towne CW, Wentworth EN (1950) Pigs from cave to cornbelt. University of Oklahoma Press, Norman

Trimble (2008) TerraSync, GPS Pathfinder Office. Sunnyvale, CA http:// www.trimble.com

Welander J (2000) Spatial and temporal dynamics of wild boar (Sus scrofa) rooting in a mosaic landscape. J Zool 252:263-271

Figures 1, 3, and 4 are EPS files, derived completely within ArcGIS version 9.3.1 (Fig. 1) and from Microsoft Excel/PowerPoint and then ArcGIS (Figs. 3 and 4). Figures 2 and 5 are TIFF files created within ArcGIS. 